Prace Historyczno-Archiwalne t. XXXII

ISSN: 1231-3335

\title{
RECENZJE
}

\section{Katarzyna Pabis-Cisowska, Postęp kontra tradycja. Kwestia małżeństwa, dobroczynności i szkolnictwa w żydowskim Krakowie na przełomie XIX i XX w., Wydawnictwo Naukowe Uniwersytetu Pedagogicznego w Krakowie, Kraków 2019, ss. 390} doktorskiej, obronionej na Wydziale Historycznym Uniwersytetu Jagiellońskiego w 2010 roku. Autorka dokonała istotnych modyfikacji pierwotnego tekstu, poszerzając zakres merytorycznych rozważań. Zmodyfikowała także tytuł pracy, słusznie precyzując przy tym ramy chronologiczne analizowanych zagadnień.

Użyte w tytule słowo „postęp”, dające szerokie pole do interpretacji, w tym wypadku zestawione na zasadzie kontrastu z określeniem „tradycja”, dość dobrze oddaje sedno rozważań, którym autorka poświęciła swą uwagę. Jak słusznie zauważył ceniony badacz dziejów XIX wieku, profesor Tomasz Kizwalter: „Postęp” to słowo, które zrobiło wielką karierę w XIX-wiecznej Europie. Mówiono o nim i pisano tak często, w odniesieniu do tak wielu zjawisk i w tak rozmaitym tonie, że jego znaczenie stawało się bardzo płynne. Niewątpliwie kojarzyło się jednak $z$ wielkq zmianq cywilizacyjnq - rozmaicie przedstawianq i ocenianq ${ }^{1}$.

W swych rozważaniach dotyczących charakterystycznych cech przemian, dokonujących się w społeczności krakowskich Żydów na przełomie XIX i XX wieku, Katarzyna Pabis-Cisowska skoncentrowała uwagę na trzech istotnych kwestiach: małżeństwa, dobroczynności oraz szkolnictwa. Dokonanie takiego wyboru przedmiotu analizy, w postaci zagadnień nieco „oderwanych” od siebie (na przykład kwestia małżeństwa, związanego integralnie z życiem religijnym, zwykle przedstawiana jest w odniesieniu do cyklu życia), może być dyskusyjne i sprawiać wrażenie braku jednoznacznej, klarownej koncepcji omawianej publikacji. Autorka słusznie więc próbuje swój wybór uzasadnić bardzo ważnym znaczeniem tych właśnie elementów w tradycji żydowskiej, zarówno w średniowieczu, jak w czasach nowożytnych do XIX i XX wieku. Wskazuje przy tym na ich wzajemne oddziaływanie oraz przenikanie, jako porządków życia zbiorowego społeczności żydowskiej.

Badania w zakresie niektórych zagadnień poruszanych w omawianej książce mogą się wykazać coraz większym dorobkiem w historiografii. Jest to widoczne szczególnie

1 T. Kizwalter. Rec.: Alicja Maślak-Maciejewska, Modlili się w Templu. Krakowscy Żydzi postępowi w XIX wieku. Studium społeczno-religijne, Wydawnictwo Uniwersytetu Jagiellońskiego, Kraków 2018, ss. 473 („Studia nad Cywilizacją Żydowską w Polsce”, pod red. Michała Galasa) - „Studia Judaica” 2019, nr 2(44), s. 358. 
w odniesieniu do kwestii dobroczynności. Do problematyki tej odnoszą się między innymi najnowsze publikacje Hanny Kozińskiej-Witt² czy Alicji Maślak-Maciejewskiej³ ${ }^{3}$

W obrębie zagadnień małżeństwa, dobroczynności i szkolnictwa, poruszanych przez autorkę omawianej publikacji, dostrzec można dobrze dokonujące się wówczas zmiany cywilizacyjne, procesy modernizacyjne, polegające na stopniowym odchodzeniu od tradycji. Na terenie Galicji, gdzie społeczność żydowska stanowiła znaczny odsetek mieszkańców (pod koniec XIX wieku ponad 11\%), było to szczególnie widoczne w dużych miastach, będących jednocześnie dużymi skupiskami ludności żydowskiej - takich jak Kraków czy Lwów. W 1910 roku Kraków liczył 32321 osób wyznających judaizm (21,3\% ogółu ludności), a Lwów - 57387 osób (27,8\% ogółu ${ }^{4}$. Na dokonujące się w środowisku ludności żydowskiej procesy modernizacyjne miały wpływ liczne w tych miastach szkoły średnie oraz uniwersytety, z których również młodzież żydowska w stosunkowo dużym stopniu korzystała. Na Uniwersytecie Jagiellońskim w pierwszym semestrze roku akademickiego 1917/1918, na ogólną liczbę 2497 studentów, 734 (29,4\%) było Żydami5 ${ }^{5}$.

Omawiana publikacja jest stosunkowo obszerna. Składa się ze wstępu, trzech rozdziałów merytorycznych, zakończenia, aneksu, bibliografii oraz spisu tabel i wykresów. Przyjęty przez autorkę chronologiczno-problemowy układ materiału jest uzasadniony i stanowi naturalną konsekwencję charakteru rozpatrywanych zagadnień. Schemat pracy, a przede wszystkim kwestia wyboru do analizy określonych źródeł i problemów, w pewnym stopniu wynika również ze znacznych nieraz braków w bazie źródłowej, odnoszącej się do społeczności żydowskiej Krakowa.

We stępie zawarte zostały wyjaśnienia dotyczące stosowanej terminologii, przyjętych ram chronologicznych i terytorialnych, poruszanej problematyki, przyjętej metodologii, wykorzystanej bazy źródłowej oraz rozważania odnoszące się do stanu badań nad dziejami krakowskich Żydów z przełomu XIX i XX wieku. Pierwszy rozdział - Od żydowskich zaślubin do rozwodu, poświęcony został problematyce przemian dotyczących zaręczyn, zaślubin, wesela, a także rozwodu. Ponadto zawiera on interesującą analizę statystyki małżeństw żydowskiego okręgu metrykalnego w Krakowie. W rozdziale drugim, Cedaka - żydowska dobroczynność, omówione zostały podstawy działalności charytatywnej oraz znaczenie dobroczynności i jej miejsce w tradycji żydowskiej. Zasadniczą jednak jego część stanowią rozważania poświęcone przemianom form działalności dobroczynnej i stosunku społeczności żydowskiej Krakowa do problemu wsparcia dla ubogich. Natomiast ostatni, trzeci rozdział - Szkolnictwo żydowskie, zawiera bardzo interesujące wyniki analizy, dotyczącej tradycyjnych i nowych form edukacji w Krakowie, w tym uczestnictwa młodzieży żydowskiej w szkolnictwie wyższym, a także odnosi się do działalności nauczycieli i nowych podręczników szkolnych. Ważnym uzupełnieniem rozważań autorki jest aneks. Zawiera on cenne dokumenty dotyczące zagadnień poruszanych w poszczególnych rozdziałach - materiały w większości dotychczas niepublikowane, a także wyda-

2 H. Kozińska-Witt, Miłosierdzie gminy miejskiej? Samorzq̨dowe subsydia dla krakowskich instytucji żydowskich w latach autonomii galicyjskiej, 1866-1914 [w:] Z dziejów i kultury Żydów w Galicji, red. M. Galas, W. Wierzbieniec, Rzeszów 2018, s. 11-35.

3 A. Maślak-Maciejewska, Modlili się w Templu. Krakowscy Żydzi postępowi w XIX wieku. Studium społeczno-religijne, Kraków 2018.

4 B. Wasiutyński, Ludność żydowska w Polsce w wiekach XIX i XX. Studium statystyczne, Warszawa 1930, s. 111, 116.

5 M. Kulczykowski, Żydzi - studenci Uniwersytetu Jagiellońskiego w dobie autonomicznej Galicji (1967-1918), Kraków 1995, s. 66. 
ne w XIX wieku, w trudno dostępnych obecnie publikacjach. Należy przy tym zaznaczyć, że poddane analizie przemiany, w wybranych przez autorkę płaszczyznach aktywności ludności żydowskiej, w stosunkowo dużym stopniu wynikały z konstytucji monarchii habsburskiej oraz ustawy o stosunku Kościoła do państwa. Te akty prawne formalnie zapewniały bowiem Żydom równouprawnienie.

Autorka wnikliwie prześledziła dokonujące się przekształcenia. Kwestie małżeństwa, dobroczynności i szkolnictwa, którym poświęciła swoją uwagę, odnosiły się do trzech istotnych obszarów życia codziennego krakowskich Żydów. W rezultacie podjęła niełatwy, wielowarstwowy problem - zasadniczo mieszczący się w nurcie historii, ale w pewnym stopniu stanowiący także dziedzinę zainteresowań religioznawców czy etnografów. Wskazując, że w Galicji w dobie autonomicznej nastąpił wyraźny proces modernizacji społeczności żydowskiej, odniosła się nie tylko do dziejów krakowskich Żydów, ale szerzej - Żydów galicyjskich w tym okresie. Starała się przy tym dociec, na ile prawidłowości dostrzegane w makroskali znajdują potwierdzenie w mikroskali - w tym przypadku społeczności żydowskiej zamieszkującej Kraków.

Wyniki szczegółowych badań autorki pozwalają na wyraziste zegzemplifikowanie wielu dotychczasowych tez, formułowanych niekiedy w wielkim przybliżeniu. W rezultacie autorka wpisuje się swoją książką w mający już sporą tradycję nurt badań nad dziejami lokalnych społeczności żydowskich na ziemiach polskich w XIX i XX wieku. W okresie, w którym ludność żydowską charakteryzował olbrzymi potencjał energii twórczej, a także wieloogniskowość życia społecznego - szczególnie w dużych miastach.

Lektura tej interesującej i ważnej publikacji skłania do refleksji, że należałoby przeprowadzić szerokie badania porównawcze, odnoszące się do poruszanych przez autorkę kwestii, obejmujące również inne miasta i miasteczka na terenie ówczesnej Galicji. Powinny one uwzględnić także mniejsze, kilkutysięczne skupiska ludności żydowskiej, jakimi były wówczas przykładowo: Bochnia, Drohobycz, Gorlice, Nowy Sącz, Rawa Ruska, jak i liczące kilkuset Żydów miasteczka, do których zaliczały się m.in.: Błażowa, Grybów, Mikołajów, Niżankowice, Pilzno czy Stara Sól. Może się to bowiem w istotny sposób przyczynić do lepszego poznania zakresu i głębi procesów modernizacyjnych, polegających na stopniowym odchodzeniu od tradycji i związanych z tym zmian mentalnościowych wśród ludności żydowskiej.

Omawiana publikacja zasługuje na uwagę czytelników, choćby z tego względu, że poruszone w niej kwestie małżeństwa, dobroczynności oraz szkolnictwa, w odniesieniu do krakowskich Żydów w drugiej połowie XIX i na początku XX wieku, wciąż jeszcze nie znalazły wystarczającego odzwierciedlenia w opracowaniach historycznych. Książka ma naukowy charakter, nie znaczy to jednak, że może wzbudzać zainteresowanie tylko wśród profesjonalistów, naukowców niejako zawodowo zajmujących się poruszanymi w niej problemami. Uważam, że zyskać może znacznie szerszy odbiór społeczny, wśród wielu innych osób, zainteresowanych historią i kulturą krakowskich Żydów.

Wacław Wierzbieniec ORCID 0000-0001-8830-9982

DOI: $10.30657 /$ pha.32.2020.17

Uniwersytet Rzeszowski e-mail:wacwie@ur.edu.pl 